\title{
Розовая гниль картофеля - опасное заболевание для южных регионов России
}

\section{М.Д. Ерохова, М.А. Кузнецова}

Описано такое заболевание картофеля как розовая гниль картофеля, вызываемое оомицетом Phytophthora erythroseptica. Показаны симптомы заболевания и присутствие возбудителей этого патогена в России и мире. Рекомендовано в случае появления Phytophthora erythroseptica на полях и в картофелехранилищах проведение комплекса мероприятий в рамках интегрированной системы защиты от этого заболевания.

Ключевые слова: Phytophthora erythroseptica, розовая гниль картофеля, интегрированная защита.

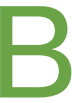

последнее время в России нарастает опасность интродукции и широкого распространения опасных патогенов из Европы. Многие из них признаны особо вредоносными через придание им официального статуса регулируемых НОКЗР организмов.

Цель нашей работы - ознакомление отечественных картофелеводов с заболеванием розовая гниль картофеля, вызываемым оомицетом Phytophthora erythroseptica.

Опасность Phytophthora erythroseptica для картофеля признается через придание патогену в 1992 году статуса рекомендуемого к регулированию вредного организма в качестве карантинного в COSAVE [1]. C 2018 года в ЕОКЗР этому патогену придан статус регулируемого некарантинного вредного организма (РНКВО) на семенном картофеле в рамках проекта EC и EOKЗР (контракт SANTE/2016/G1/ SI2.726941) [2, 3]. На текущий момент в ЕАЭС Phytophthora erythroseptica не имеет статуса карантинного или регулируемого некарантинного вредного организма, однако, по сведениям ЕОКЗР и САВІ, патоген широко распространен в мире, особенно в странах с теплым климатом [1].

Особенно опасно для России присутствие этого патогена в европейских странах, из которых активно импортируется семенной картофель. По данным НОКЗР Нидерландов, розовая гниль была уже широко распространена в этой стране в 1993 году [1].
Международные организации, занимающиеся мониторингом патогенов, признают присутствие Phytophthora erythroseptica и в России. По информации САВІ, В России патоген присутствует с 1990 года, но детальных сведений об этом нет [4]. В нашей страности этого патогена до сих пор не проводился. По состоянию на 2019 год Россельхозцентр подне мониторинг распространен- твердил, что не проводит диагностику Phytophthora erythroseptica в рамках добровольной сертификации семенного картофеля. В действующем ГОСТ 33996-2016 нет нормативов содержания по Phytophthora erythroseptica в ceменном картофеле, за исключением допусков по мокрым гнилям.

Описание симптомов заболевания и методов его контроля будут полезны производителям картофеля для идентификации болезни. Фотографии симптомов заболевания имеются в онлайн-руководстве по заболеваниям и дефектам картофеля ЕЭК ООН [5].

Как правило, розовая гниль не проявляется на листьях и стеблях картофеля, за исключением появления некроза на нижней части стеблей при сильной степени развития болезни. На корнях

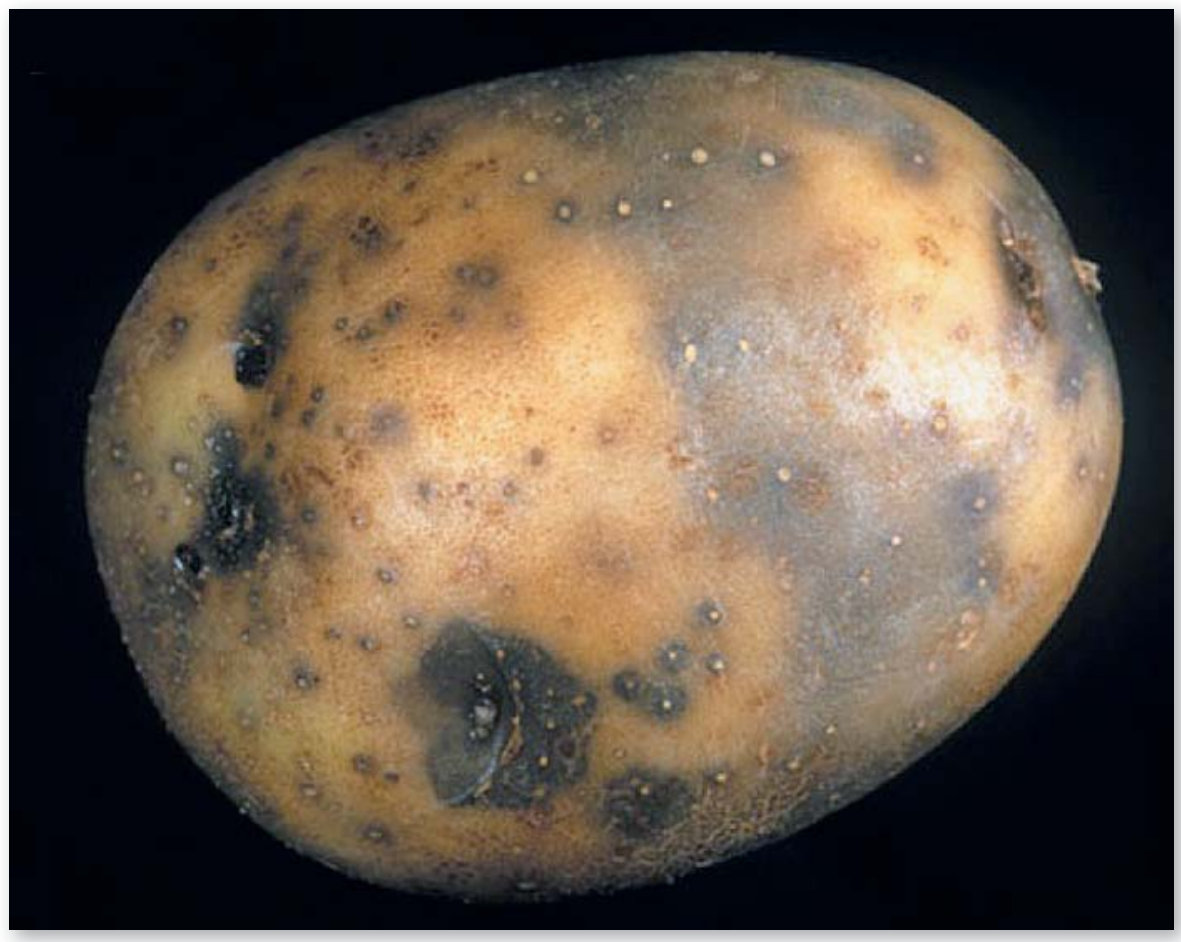

Поверхность клубня картофеля, пораженного розовой гнилью 


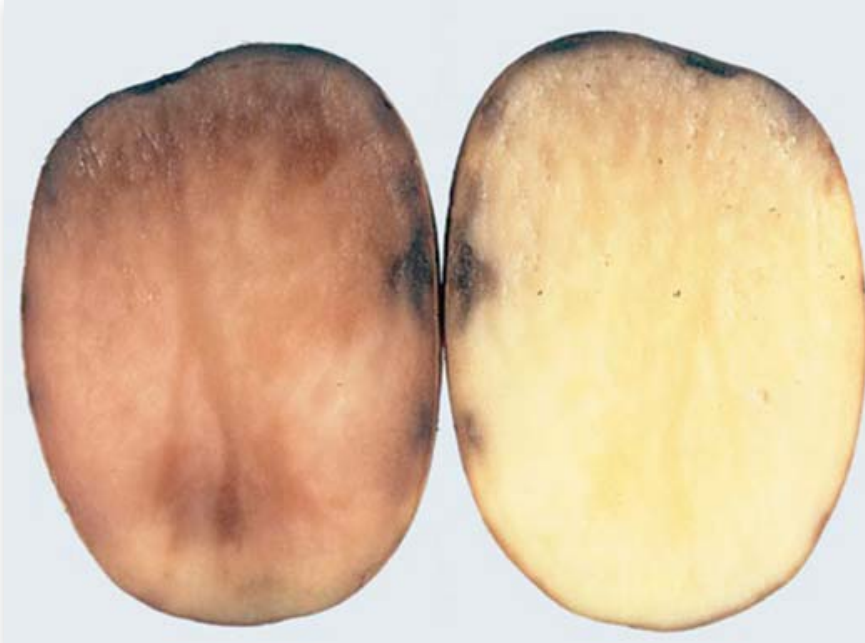

Пораженный клубень в разрезе

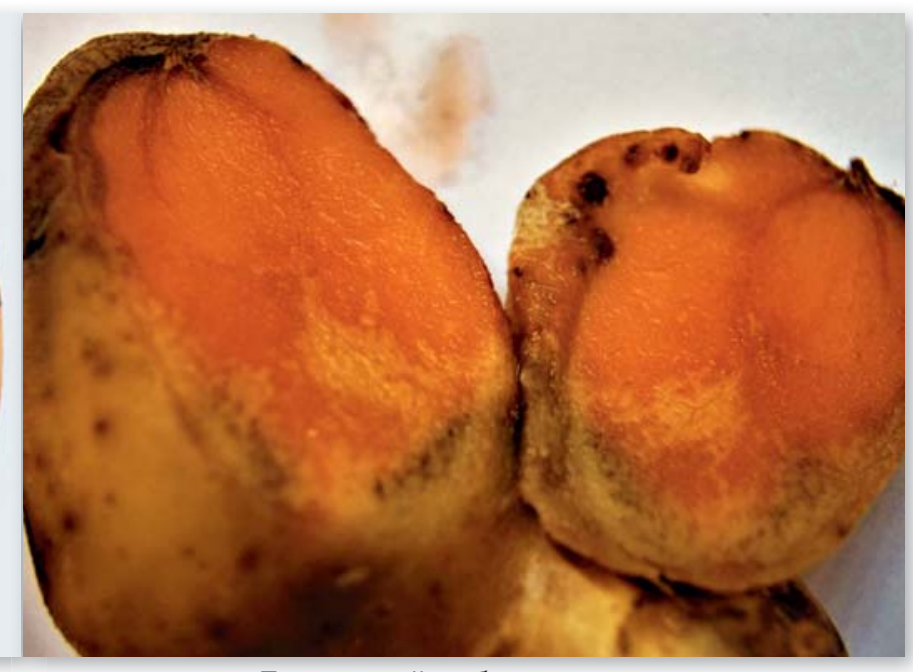

Пораженный клубень в разрезе и столонах обычно появляются светло-коричневые пятна или полосы [6].

Клубни поражаются через столоны, глазки, чечевички и повреждения, на них появляются темно-коричневые пятна вокруг глазков и чечевичек [6]. Темная линия на поверхности клубня очерчивает распространение инфекции, при этом зараженные ткани становятся мягкими. Внутреннее гниение ткани клубня начинается со столонной части. При сжатии разрезанные клубни выделяют прозрачную жидкость без запаха. На воздухе разрезанная поверхность клубня розовеет, затем темнеет до коричневого или черного цвета. При дальнейшем развитии болезни появляется мокрая гниль, ткань клубня полностью разрушается.

Наибольшая вредоносность розовой гнили наблюдается на переувлажненных почвах при температуре почвы выше $+20{ }^{\circ} \mathrm{C}$, но патоген способен развиваться в широком диапазоне температур - от 5 до $33^{\circ} \mathrm{C}$ [6]. Будучи почвенным патогеном, гриб сохраняется в почве и распространяется с зараженными растительными остатками. Зооспоры остаются основным источником инфекции в почве, передвигаясь с помощью почвенной влаги и заражая здоровые клубни. Больные клубни могут загнивать при хранении и заражать здоровые; при слабой инфицированности больные клубни могут сохраняться и становятся источником инфекции в поле.

Для снижения вредоносности розовой гнили картофеля следует проводить комплекс мероприятий в рамках интегрированной защиты от этого заболевания.
Семеноводческие:

- государственный

контроль Phytophthora erythroseptica в рамках национальной сертификации семенного картофеля;

- использование для посадки здорового семенного картофеля;

- яровизация семенного картофеля, посадка в прогретую почву.

Агротехнические:

- соблюдение севооборота с ротацией не менее 4 года;

- обеспечение сбалансированного внесения удобрений;

- сдерживание переносчиков и резерваторов болезни;

- бережная уборка при оптимальных температурах воздуха.

Химические:

- внесение при посадке клубней препарата ЮНИФОРМ® 1,5 л/га [7];

- предуборочное удаление ботвЫ (РЕГЛОН® ФОРТЕ + ШИРЛАН®) этот прием способствует контролю грибных и бактериальных патогенов, уничтожению сорняков, повышению прочности кожуры клубней, снижению повреждений при уборке;

- обработка семенных клубней перед закладкой на хранение препаратом МАКСИМ® 0,2 л/т.

Хранение:

- дезинфекция хранилищ и соблюдение режимов хранения;

- обеспечение лечебного периода (2-3 недели) при температуре 12$18^{\circ} \mathrm{C}$, влажности воздуха 90-95\%).

\section{Библиографический список}

1.EPPO (2019). EPPO Global Database [web resource] URL: https://gd.eppo.int. Access date: 05.10.19.

2.Picard C. et al. Recommended regulated nonquarantine pests (RNQPs), associated thresholds and risk management measures in the European and Mediterranean region // EPPO Bulletin. 2018. 48 (3). Pp. 552-568. DOI: 10.1111/epp. 12500.
3.Picard C. et al. Recommended Regulated NonQuarantine Pests: towards a wider and better application of the international concept in the EPPO region // Biotechnol Agron. Soc. Environ. 2019. 23 (1). Pp. 36-45.

4.CABI. Distribution Maps of Plant Diseases. 1990 № 083. Wallingford. UK: CAB Inernational.

5.UNECE Guide to Seed Potatoes Diseases, Pests and Defects [web resource] URL: hort.azurewebsites.net/\#!/ search. Access date: 11.04.19.

6.Wale S., Platt (Bud) H. W., Cattlin N. Diseases, pests and disorders of potatoes. Manson Publishing Ltd., 2008. $176 \mathrm{p}$.

7.ЮНИФОРМ® против болезней картофеля / М.А. Кузнецова, А.Н. Рогожин, Т.И. Сметанина, И.А. Денисенков // Картофель и овощи. 2015. № 5. С. 24-26.

\section{Об авторах}

\section{Ерохова Мария Дмитриевна,} м.н.c. E-mail: maria.erokhova@gmail. com

Кузнецова Мария Алексеевна, канд. биол. наук, зав. отделом болезней картофеля и овощных культур Всероссийский научно-исследовательский институт фитопатологии (ФГБНУ ВНИИФ)

Pink rot of potato is a dangerous disease for the southern regions of Russia M.D. Erohova, junior research fellow. E-mail: maria.erokhova@gmail.com M.A. Kuznecova, PhD, head of Department of potato and vegetable diseases All-Russian Research Institute of Phytopathology (FSBSI ARRIP)

Summary. Described this disease of the potato pink rot of potatoes caused by Phytophthora erythroseptica oomycetes. The symptoms of the disease and the presence of pathogens of this pathogen in Russia and the world are shown. In case of emerging of Phytophthora erythroseptica in fields and potato storages, the Integrated Disease Management against this pest needs implementing.

Keywords: Phytophthora erythroseptica, pink rot of potato, Integrated Disease Management. 